\title{
In vitro growth and leaf anatomy of Cattleya walkeriana (Gardner, 1839) grown in natural ventilation system
}

\author{
Adriano Bortolotti da Silva ${ }^{1}$, Poliana Patrícia Lima² Livia Emanuelle Simao de Oliveira ${ }^{3}$, Andre Luis Moreira ${ }^{4}$
}

http://dx.doi.org/10.1590/0034-737X201461060001

\begin{abstract}
Natural ventilation system facilitates gaseous exchanges in in vitro plants promoting changes in the leaf tissue, which can be evaluated through the leaf anatomy, and it allows a cultivation closer to the photoautrophic micropropagation. The objective of this work was to evaluate the effects on in vitro growth and on the leaf anatomy of Cattleya walkeriana grown in natural and conventional ventilation system with different concentrations of sucrose $\left(0 ; 15 ; 30\right.$ and $\left.45 \mathrm{~L}^{-1}\right)$ combined with different cultivation systems (conventional micropropagation and natural ventilation system). The culture medium was composed of MS salts, solidified with $7 \mathrm{~g} \mathrm{~L}^{-1}$ of agar and $\mathrm{pH}$ adjusted to 5.8. Forty milliliters of culture medium were distributed in $250 \mathrm{~mL}$ flasks, autoclaved at $120{ }^{\circ} \mathrm{C}$ for 20 minutes. The greater plant growth, as well as the greater thickness of the mesophyll was observed with the use of $20 \mathrm{~g} \mathrm{~L}^{-1}$ sucrose in natural ventilation system. Plants grown in natural ventilation system showed a thicker leaf mesophyll, which is directly related to photoautotrophic crops. The natural ventilation system induced more elliptical stomata and probably more functional formats.
\end{abstract}

Key words: micropropagation, orchids, tissue culture, gases exchanges.

\section{RESUMO}

\section{Crescimento in vitro e anatomia foliar de Cattleya walkeriana (Gardner, 1839) cultivada em sistema de ventilação natural}

O sistema de ventilação natural facilita as trocas gasosas, em plantas cultivadas in vitro, ocasiona mudanças no tecido foliar, as quais podem ser avaliadas pela anatomia foliar, e possibilita um cultivo mais próximo ao da micropropagação fotoautotrófica. Este trabalho teve por objetivo avaliar os efeitos no crescimento in vitro e na anatomia foliar de Cattleya walkeriana, cultivadas em sistemas de ventilação natural e convencional, com diferentes concentrações de sacarose. As plantas receberam concentrações variadas de sacarose $\left(0,15,30 \mathrm{e} 45 \mathrm{~g} \mathrm{~L}^{-1}\right)$, em combinação com diferentes sistemas de cultivo (micropropagação convencional e sistema de ventilação natural). $\mathrm{O}$ meio de cultura foi composto pelos sais do meio MS, solidificado com $7 \mathrm{~g} \mathrm{~L}^{-1}$ de ágar, sendo o $\mathrm{pH}$ ajustado para 5,8. Foram distribuídos $40 \mathrm{~mL}$ de meio de cultura, em frascos de $250 \mathrm{~mL}$ de conteúdo, os quais foram autoclavados, a $120{ }^{\circ} \mathrm{C}$, por 20 minutos. $\mathrm{O}$ maior crescimento das plantas, bem como a maior espessura do mesofilo, foram observados, com emprego de $20 \mathrm{~g} \mathrm{~L}^{-1}$ de sacarose, em sistema de ventilação natural. As plantas cultivadas em sistema de ventilação natural apresentaram maior espessura do mesofilo foliar, resposta diretamente relacionada com cultivos fotoautotróficos. O sistema de ventilação natural proporcionou estômatos com o formato mais elípticos e, possivelmente, mais funcionais.

Palavras-chave: micropropagação, orquídea, cultura de tecidos, trocas gasosas.

Recebido para publicação em 23/02/2012 e aprovado em 01/08/2014.

${ }^{1}$ Agronomist, Doctor of Science. Faculdade de Agronomia, Universidade José do Rosário Vellano, Rodovia MG 179, Km 0, Caixa Postal 23, 37130-000, Alfenas, Minas Gerais, Brazil. adriano.silva@unifenas.br (corresponding author).

${ }^{2}$ Undergraduate student. Faculdade de Agronomia, Universidade José do Rosário Vellano, Rodovia MG 179, Km 0, Caixa Postal 23, 37130-000, Alfenas, Minas Gerais, Brazil liamanuele@gmail.com

${ }^{3}$ Undergraduate student. Faculdade de Agronomia, Universidade José do Rosário Vellano, Rodovia MG 179, Km 0, Caixa Postal 23, 37130-000, Alfenas, Minas Gerais, Brazil. polly_alp@hotmail.com

${ }^{4}$ Agronomist. Faculdade de Agronomia, Universidade José do Rosario Vellano, Rodovia MG 179, Km 0, Caixa Postal 23, 37130-000, Alfenas, Minas Gerais, Brazil. dede_alm@yahoo.com.br 


\section{INTRODUCTION}

The Orchidaceae family has about 850 genera and 20,000 species, excluding artificial hybrids. It is the largest family among angiosperms. They are cultivated because of the beauty and exoticity of their flowers, presenting a cosmopolitan distribution, occurring in almost all regions in the world, except the poles and deserts, being more frequent and exuberant in the tropics. The high number of species and tropical hybrids enable various forms and colors of flowers, which are commercially exploited all over the world (Silva et al., 2005).

The assimbiotic cultivation of orchids reduces the effects of predatory collection of these plants in the woods since it results in almost $100 \%$ of germination of their seeds (Campos, 2000), presenting a much higher yield to that observed in nature, which is around $2 \%$ to $3 \%$. This low germination yield is due mainly to the need for association among the seeds of orchids with Micorriza fungus, which occurs at low frequency in nature (Araujo et al., 2009).

Micropropagation of plants can be used for largescale production of orchid seedlings from the seed germination and in vitro growth of plants, being a widely used technique in difficult propagation plants. However, the development of methods that provide a greater plant growth and a reduction of physiological and anatomical disorders is necessary to reduce losses in the acclimatization (Mills et al., 1997).

Different cultivation systems have been used to increase the photosynthetic rate, the production of hardened plants and the reduction of losses of micropropagated plants. The following methods stand out: the use of caps or bottles that allow gas exchange (Kubota \& Kozai, 1992); the increase in light intensity (Fuentes et al., 2005); $\mathrm{CO}_{2}$ injection in the culture (Argita, 2002); reduction in carbohydrate source in the culture medium (Kozai, 1991) or a combination of these methods.

The in vitro cultivation with the use of bottles and caps that allow gas exchange is named the natural ventilation system (Kozai \& Kubota, 1992). This system allows the reduction of the relative humidity inside the culture flask (Pérez-Tornero et al., 2001), the increase in gas exchange with the external atmosphere (Buysens \& Dillen, 1989) and the decrease in water availability, factors which can provide favorable environmental conditions for photoautotrophic micropropagation (Kanechi et al., 1998). Environmental changes in the in vitro cultivation can lead to changes in the tissues, which can be evidenced by studies of leaf anatomy of the plants grown in these systems. The leaves of Cattleya sp. are hypostomatic type, with anomocytic stomata, with uniseriate epidermis and homogeneous parenchyma chlorophyll (Araujo et al., 2009).

Therefore, the objective of this work was to evaluate the effects on the in vitro growth and on the leaf anatomy of Cattleya walkeriana, grown in different concentrations of sucrose on natural ventilation system and conventional micropropagation system.

\section{MATERIALAND METHODS}

This work was carried out at the Laboratory of Plant Biotechnology, José do Rosário Vellano University (UNIFENAS) in Alfenas, State of Minas Gerais, Brazil. The plants were obtained by seed germination, from the self-pollination of Cattleya walkeriana in Knudson culture medium (1922), added with $20 \mathrm{~g} \mathrm{~L}^{-1}$ sucrose and solidified with $7 \mathrm{~g} \mathrm{~L}^{-1}$ agar. Plants were standardized at 1 $\mathrm{cm}$ for experiment setting up.

The treatments consisted of different sucrose concentrations $\left(0,15,30\right.$ and $\left.45 \mathrm{~g} \mathrm{~L}^{-1}\right)$ combined with different cultivation systems (natural ventilation system and conventional micropropagation). For all treatments, the culture medium consisted of salts of Murashige \& Skoog Medium (1962), and $\mathrm{pH}$ adjusted to 5.8 and solidified with the use of $7 \mathrm{~g} \mathrm{~L}^{-1}$ agar. It was distributed $40 \mathrm{ml}$ of culture medium in 250-ml flasks, which were identified according to each treatment and autoclaved at $120^{\circ} \mathrm{C}$ for 20 minutes. Cultivation was maintained in a growth room with temperature of $24 \pm 2{ }^{\circ} \mathrm{C}$, light intensity of $36 \mu \mathrm{m}^{-2} \mathrm{~s}^{-1}$ and a 16-hour photoperiod.

In the natural ventilation system, a plastic lid was manufactured for the cultivation flask. This lid had two circular holes, each one with $10 \mathrm{~mm}$ in diameter, which were covered with a filter membrane with 0.5 - $\mu$ m pores (Milli Seal, Millipore, Tokyo, Japan). For conventional micropropagation, plastic caps were used, which sealed completely the cultivation flasks, preventing the occurrence of gas exchange with the external environment.

After 180 days, the following were evaluated: the length of shoot and root system, the fresh and dry weight of shoot and root system. For leaf anatomy, the following were evaluated: thickness of the mesophyll and epidermis on the adaxial side and on the abaxial surface, leaf thickness, polar and equatorial diameter of the stomata.

The plants used in anatomical studies were collected and stored in alcohol at $70^{\circ} \mathrm{GL}$. Leaf sections were free hand cut. Cross sections were clarified in a $1 \%$ sodium hypochlorite solution, then rinsed in distilled water and stained with astra- Safranin blue dye. Slides were set in $50 \%$ glycerin, following the methodology described by 
Kraus \& Arduin (1997). From the cross sections and with the aid of an ocular micrometric, thickness of the tissue in the middle third of each leaf was measured. The treatments consisted of four replicates with four plants per plot, in which one leaf of each plot was evaluated, totaling 16 leaf blades per treatment.

The paradermal cuts were performed on the abaxial surface, in the middle region of the leaves, and the hydroalcoholic safranin $1 \%$ was used as a dye for setting up the slides. The polar and equatorial diameters of the stomata was obtained with the use of ocular micrometric. In each evaluated leaf, three stomata were measured to obtain the polar and equatorial diameters.
Photomicrographs were performed using OLYMPUS BX - 60 photomicroscope.

It was used a completely randomized design (CRD), consisting of a $4 \times 2$ simple factorial, with four replications and four plants per plot. Analysis of variance was carried out using the statistical program Sisvar (Ferreira, 2000), being performed a polynomial regression.

\section{RESULTS AND DISCUSSION}

The length of the shoot was directly affected by the cultivation system (Figure 1A). Longer shoot length was found in natural ventilation system, using $20.30 \mathrm{~g} \mathrm{~L}^{-1}$
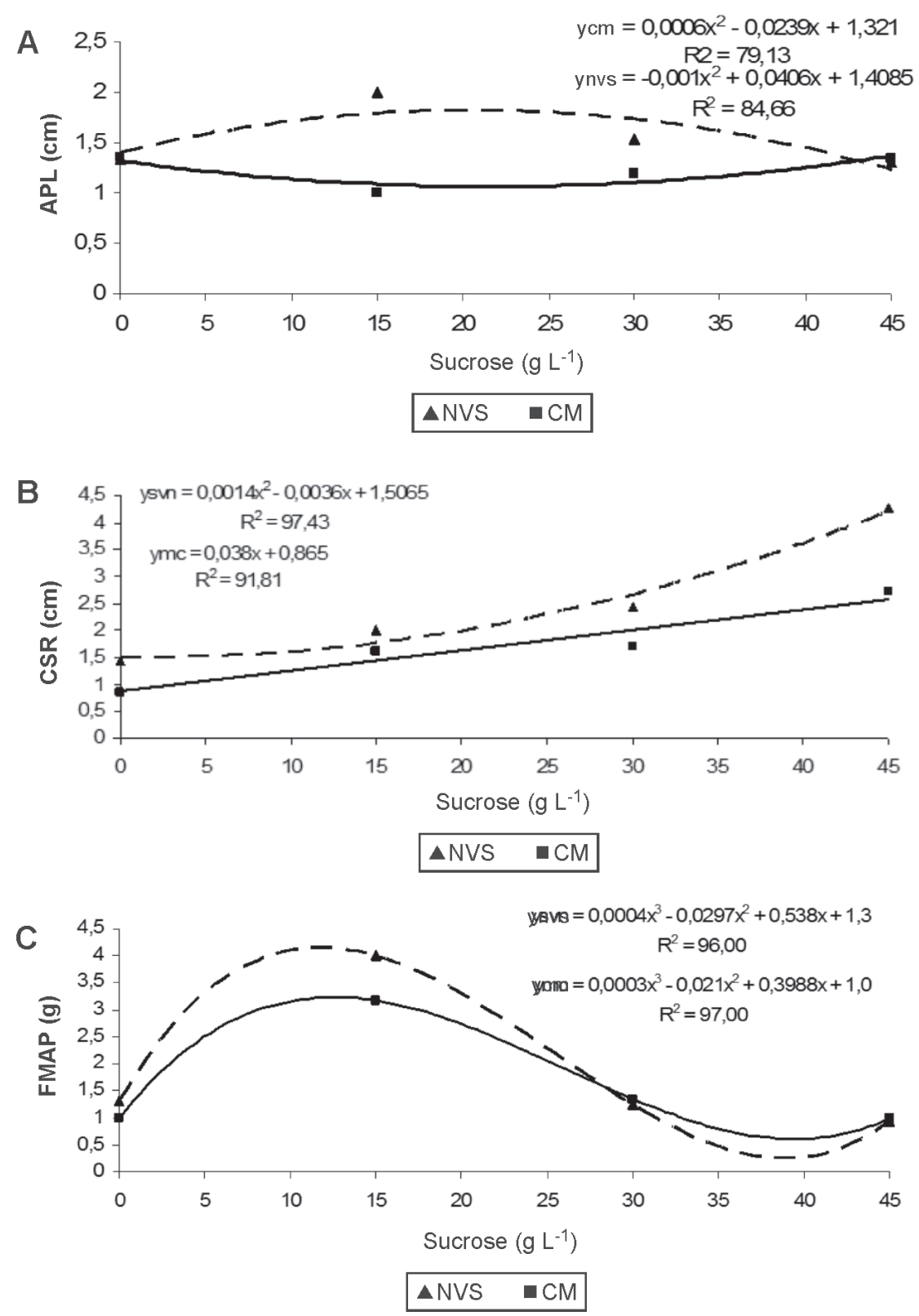

Figure 1. In vitro growth of $C$. walkeriana according to different concentrations of sucrose and cultivation environments. A) aerial part length (APL); B) length of the root system (LRS); C) fresh mass of the aerial part (FMAP). Conventional micropropagation (CM) and natural ventilation system (NVS). 
sucrose, point from which the shoot showed a decreasing trend of its length as concentrations of sucrose increased. Mills et al. (2004) observed a longer length of the buds in photomixotrophic cultivation of jojoba in the natural ventilation system.

Unlike the shoots, the length of the root system showed greater growth in the culture medium with high concentration of sucrose $\left(45 \mathrm{~g} \mathrm{~L}^{-1}\right)$ in combination with the natural ventilation system (Figure 1B). Sucrose is one of the main factors involved in the in vitro rooting (Grattapaglia \& Machado, 1998) and in this work, the increase in concentrations of sucrose induced higher root growth, regardless of the cultivation system (Figure 1B).

A better performance for fresh and dry mass of the aerial part (Figures 1C and 2B) was found in the culture medium with 10.05 and $22.92 \mathrm{~g} \mathrm{~L}^{-1}$ sucrose, respectively, in the natural ventilation system. Similar responses were observed in the natural ventilation system in a culture medium supplemented with $20 \mathrm{~g} \mathrm{~L}^{-1}$ sucrose in cauliflower crops (Kanechi et al., 1998). The natural ventilation system promoted higher dry weight of the aerial part in MS medium (Murashige \& Skoog, 1962) containing 3\% sucrose, in tomato crops (Mills \& Tal, 2004).
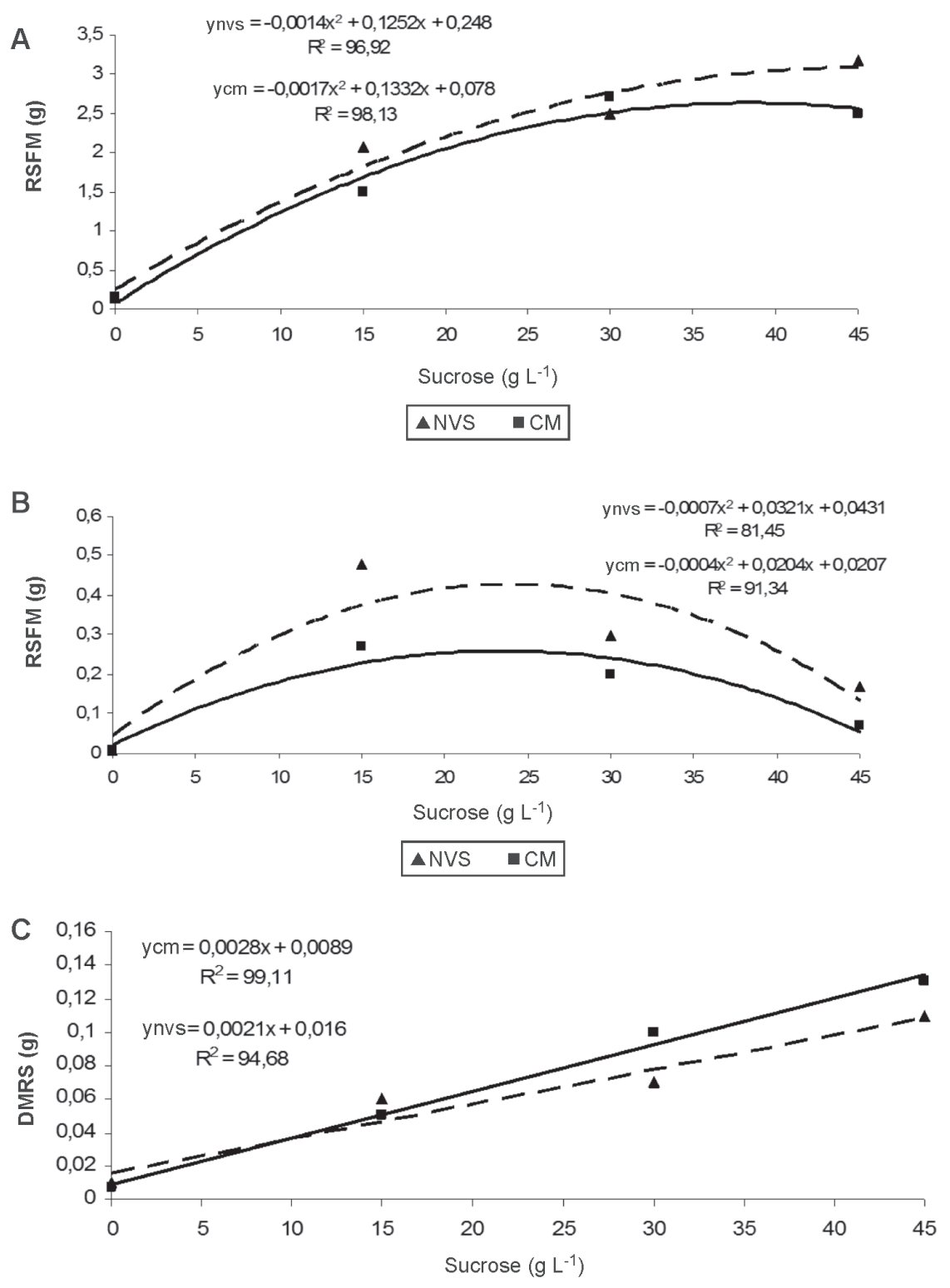

$\triangle N V S \quad \square \mathrm{CM}$

Figure 2. In vitro growth of $\mathrm{C}$. walkeriana according to different concentrations of sucrose in cultivation enviroments. A) rooth system fresh mass (RSFM); B) dry mass of the aerial part (DMAP); C) dry mass of root system (DMRS). Conventional micropropagation $(\mathrm{CM})$ and natural ventilation system (NVS). 
The root system showed higher fresh mass in the natural ventilation system, where roots growing in culture medium with $44.7 \mathrm{~g} \mathrm{~L}^{-1}$ sucrose, or using $39.17 \mathrm{~g} \mathrm{~L}^{-1}$ sucrose in conventional cultivation system (Figure $2 \mathrm{~A}$ ). For dry mass of the root system, a linear increase of dry matter occurred as concentrations of sucrose increased, in both in vitro cultivation systems (Figure 2C). Although filter membranes permit gas exchanges with the environment, and, possibly, a cultivation closer to the photoautotrophic culture, the development of the root system still directly depends on the sucrose in the culture medium. The same behavior was found by Kanechi et al. (1998), in the cauliflower grown under natural ventilation system. This dependence on
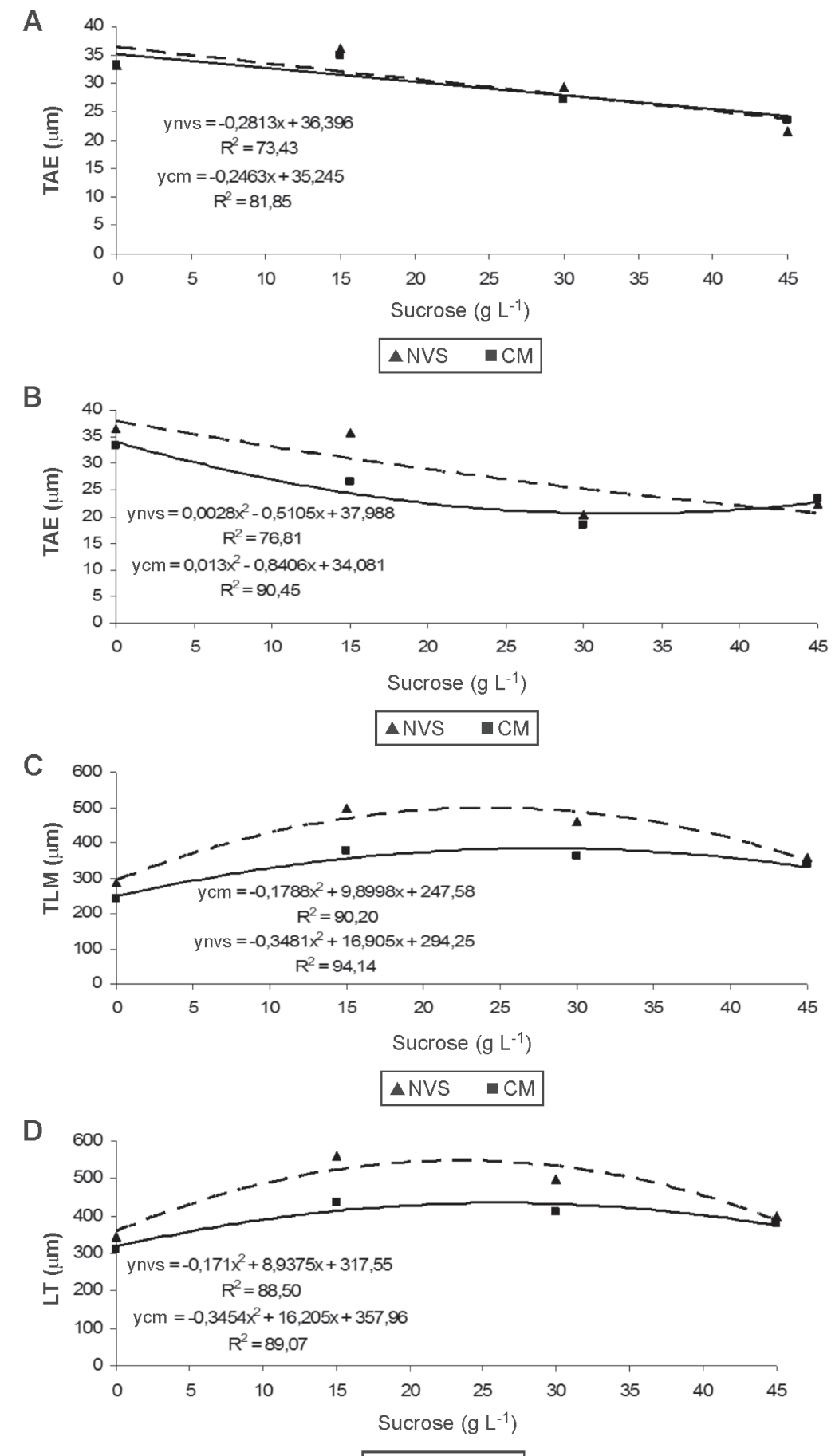

$\triangle N V S \quad$ CM

Figure 3. Leaf anatomy of $C$. walkeriana according to different concentrations of sucrose and cultivation environments. A) thickness of adaxial epidermis (TAdE); B) Thickness of abaxial epidermis (TAbE); C) Thickness of leaf mesophyll (TLM); D) Leaf thickness (LT). Conventional micropropagation (CM) and natural ventilation system (NVS). 
exogenous sucrose, for the growth of the root system, is observed in in vitro cultivations (Grattapaglia \& Machado, 1998). Probably, the energy demand during rhizogenesis is high, causing the root system to present greater development in culture medium with large availability of carbon source.

The reduction or even the elimination of sucrose in the culture medium the in natural ventilation system or conventional micropropagation promoted greater thickness of adaxial epidermal face and abaxial face of orchid plants, regardless of the cultivation system (Figures 3A and B ). Greater thickness of the leaf mesophyll was found in the natural ventilation system in a culture medium added with $24.28 \mathrm{~g} \mathrm{~L}^{-1}$ sucrose, when compared with that found in the conventional micropropagation system (Figure 3C). The cultivation of plants in the culture medium with lower sucrose levels allows a closer micropropagation to the photoautotrophic culture, as compared with the conventional micropropagation system.

The epidermis of $C$. walkeriana are uniestratified on both sides of the leaf, and the mesophyll presents homogeneous chlorophyll parenchyma. Dignart (2009) found in in vitro $C$. walkeriana, cultured under different light intensities, mesophyll similar to that found in this study (Figure 4B), and a thicker adaxial epidermis compared with the abaxial epidermis. In addition, the cells in the leaf tissue of plants grown in the natural ventilation system are better organized than those in the conventional micropropagation (Figure 4A and B).

Greater leaf thickness was found in natural ventilation system, supplemented with $23.52 \mathrm{~g}$ sucrose (Figure $3 \mathrm{D}$ ). The increase in leaf thickness is a response directly related to micropropagation in photoautotrophic culture systems (Lee et al., 2000; Smith et al., 2008) and possibly with the increase in in vitro photosynthesis rates (Khan et al., 2003; Nguyen et al., 2001; Seko \&Nishimura, 1996). According to Araujo et al. (2009), the thicker mesophyll, or the number of cell layers of the mesophyll, is related to the higher efficiency of photosynthesis, also leading to greater accumulation of dry mass of the aerial part, found in this study (Figure 2 B).

The ability to alter the leaf structure in response to the environment has been commonly observed in in vitro cultivated species (Hazarika, 2006). In addition, the natural ventilation system may have the benefit of reducing physiological changes by hyperhydricity, by reducing the in vitro relative humidity and increase gas exchange (Park
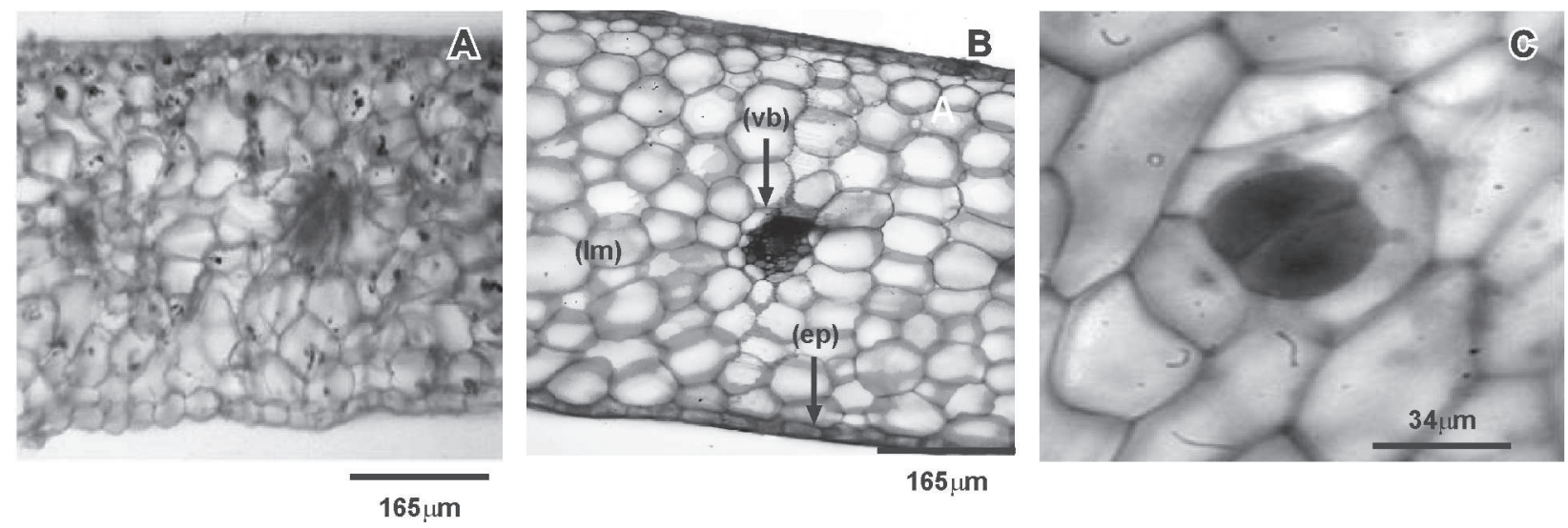

Figure 4. Photomicrographs of cross sections of the middle third of C. walkeriana leaves of plants grown in vitro in conventional micropropagation with culture medium supplemented with $20 \mathrm{~g} \mathrm{~L}^{-1}$ sucrose (A); and in natural ventilation system with culture medium with $20 \mathrm{~g} \mathrm{~L}^{-1}$ sucrose (B); epidermis (ep); vascular bundle (vb); leaf mesophyll (lm); aquifer parenchyma (paq). Paradermis section of the abaxial surface of leaves of $C$. walkeriana $(\mathrm{C})$, presenting anomocytic type stomata.

Table 1 - Leaf thickness, polar and equatorial diameter in a culture medium with different concentrations of sucrose in the culture systems

\begin{tabular}{|c|c|c|c|c|}
\hline \multirow{2}{*}{ Sucrose $\left(\mathrm{g} \cdot \mathrm{L}^{-1}\right)$} & \multicolumn{2}{|c|}{ Polar diameter * $(\mu \mathrm{m})$} & \multicolumn{2}{|c|}{ Equatorial diameter $*(\mu \mathrm{m})$} \\
\hline & NVS & $\mathbf{C M}$ & NVS & $\mathbf{C M}$ \\
\hline 0 & $30.40 \mathrm{Aa}$ & $34.00 \mathrm{Aa}$ & $28.40 \mathrm{Aa}$ & $33.50 \mathrm{Aa}$ \\
\hline 15 & 33.80Aa & $32.60 \mathrm{Aa}$ & $29.70 \mathrm{Aa}$ & $31.60 \mathrm{Aa}$ \\
\hline 30 & $32.00 \mathrm{Aa}$ & $36.00 \mathrm{Aa}$ & 29.20Aa & $35.80 \mathrm{Aa}$ \\
\hline 45 & $33.50 \mathrm{Aa}$ & 33.01Aa & $30.50 \mathrm{Aa}$ & 33.50Aa \\
\hline
\end{tabular}

Means followed by the same uppercase letter in the vertical and lowercase letter on the horizontal do not differ by the test of Skoot \& Knott at $5 \%$ of probability. * Stomata diameter.

Rev. Ceres, Viçosa, v. 61, n.6, p. 883-890, nov/dez, 2014 
et al., 2004; Casanova et al., 2008; Ivanova \& Staden, 2010) and provide good cellular organization of leaf tissue, as well as lower water loss rates in the early days of acclimatization and success of the process (Mills et al., 2004; Deccetti et al., 2008).

The leaves of $C$. walkeriana present anomocytic type stomata (Figure 4C). The equatorial and polar diameters of stomata had no response to the different treatments (Table 1). However, more elliptical stomata are reported as more functional, while the rounded shape is associated with stomata that do not function properly (Capellades et al., 1990; Khan et al., 2003). In this work, a trend in greater difference between the values of polar and equatorial diameters (Table 1) was found in this work, leading to a more elliptical shape of the stomata, when compared to the conventional micropropagation system. The natural ventilation system provided greater stomatal control in species such as Annona glabra (Deccetti et al., 2008), jojoba (Mills et al., 2004) and Aloe polyphylla (Ivanova \& Staden, 2010), which is directly related to the photoautotrophic micropropagation.

Plants of C.walkeriana presented changes in leaf anatomy in relation to the different in vitro cultivation environments, especially in relation to the thickness of the leaf mesophyll. The natural ventilation system promoted in a positive way, most biometric characteristics of growth and leaf anatomy, which are directly related to photosynthetic processes, promoting plant growth under these conditions.

\section{CONCLUSIONS}

The natural ventilation system, combined with $20 \mathrm{~g}$ $\mathrm{L}^{-1}$ sucrose, promotes, in Cattleya walkeriana, greater growth in in vitro plants, as well as higher leaf thickness and more elliptical stomata, responses that approach this micropropagation system to photoautotrophic cultivation.

\section{REFERENCES}

Araujo AG, Pasqual M, Miyata LY, Castro EM \& Rocha HS (2009) Qualidade de luz na biometria e anatomia de plântulas Cattleya loddigesii L. (Orchidaceae) micropropagadas. Ciência Rural, 39:2506-2511.

Argita L, González A \& Tamés RS (2002) Influence of $\mathrm{CO}_{2}$ and sucrose on photosynthesis and transpiration of Actinidia deliciosa explants culture in vitro. Physiologia Plantarum, 115:166-173.

Campos DM (2000) Orquídeas: manual prático de reprodução. Rio de Janeiro, Expressão e Cultura. 128p.

Capellades M, Fontarnau R, Carulla C \& Debergh P (1990) Environment influences anatomy of stomata and epidermal cells in tissue culture Rosa multiflora. Jornal of the American Society for Horticultual Science, 115:141-145.

Casanova E, Moysett L \& Trillas MI (2008) Effects of agar concentration and vessel closure on the organogenesis and hyperhydricity of adventitious carnation shoots. Biologia Plantarum, 52:1-8.
Deccetti SFC, Soares AM, Paiva R \& Castro EM (2008) Effect of the culture environment on stomatal features, epidermal cells and water loss of micropropagated Annona glabra L. plants. Scientia Horticulturae, 117:341-344.

Dignart LS, Castro EM, Pasqual M, Ferronalo A, Braga FT \& Paiva R (2009) Luz natural e concentrações de sacarose no cultivo in vitro de Cattleya walkeriana. Ciência e Agrotecnologia, 33:780-787.

Dillen W \& Buysens S (1989) A simple technique to overcome vitrification in Gypsophila paniculata L. Plant Cell Tissue Organ Culture, 19:181-188.

Ferreira DF (2000) Análises estatísticas por meio do SISVAR para windows versão 4.0. In: $45^{\mathrm{a}}$ Reunião Anual da Região Brasileira da Sociedade Internacional de Biometria, São Carlos. Anais, UFSCar. p.225-258.

Fuentes G, Talavera C, Oropeza C, Desjardins Y \& Santamaria JM (2005) Exogenous sucrose can decrease in vitro photosynthesis but improve field survival and growth of coconut (Cocos nucifera L.) in vitro plantlets. In Vitro Plant, 4:69-76.

Grattapaglia D \& Machado MA (1998) Micropropagação. In: Torres AC, Caldas LS \& Buso JA (eds.) Cultura de tecidos e transformação genética de plantas. Brasília, Embrapa. p.183-260.

Hazarika BN (2006) Morpho-physiological disorders in vitro culture of plants. Scientia Horticulturae, 108:105-120.

Ivanova M \& Staden JV (2010) Natural ventilation effectively reduces hyperhydricity in shoot cultures of Aloe polyphylla Schönland ex Pillans. Plant Growth Regulation, 60:143-150.

Kanechi M, Ochi M, Abe M, Inagaki N \& Maekawa S (1998) The effects of Carbon Dioxide Enrichment, Natural Ventilation, and Light Intensity on Growth, Photosynthesis, and Transpiration of Cauliflower Plantlets Culture in vitro Photoautotrophically and Photomixotrophically. Jornal of the American Society for Horticultual Science, 123:176-181.

Khan SV, Kozai T, Nguyen OT, Kubota C \& Dhawan V (2003) Growth and water relations of Paulownia fortunei under photomixotrophic and photoautotrophic conditions. Biologia plantarum, Copenhagen, 46:161-166.

Knudson L (1992) Nonsymbiotic germination of orchid seeds. Botanical Gazette, Chicago, 73:01-25.

Kozai T (1991) Autotrophic micropropagation. In: Bajaj YPS (Ed.) Biotechnology in Agriculture and Forestry 17: High-Tech and Micropropagation I. Springer-Verlag, New York. p.313-343.

Kraus JE \& Arduim M (1997) Manual básico de métodos em morfologia vegetal. Rio de Janeiro, EDUR. 198p.

Kubota C \& Kozai T (1992) Growth and net photosynthetic rate of Solanum tuberosum in vitro under forced and natural ventilation. HortScience, 27:1312-1314.

Lee DW, Oberbauer SF, Johnson P, Krishnapilay B, Mansor M \& Yap SK (2000) Effects of irradiance and spectral quality on leaf stucture and function in seedlings of two southeast Asian Hopea (Dipterocarpaceae) species. American Journal of Botany, 87:447-455.

Mills D, Wenkart S \& Benzioni A (1997) Micropropagation of Simmondsia chinensis (Jojoba). In: Bajaj YPS., ed. Biotechnology in agriculture and forestry, High-tech and micropropagation VI. Berlin, Springer-Verlag. p.370-393.

Mills D, Yanqing Z \& Benzioni A (2004) Improvement of Jojoba shoot Multiplication in vitro by Ventilation. In Vitro Cellular \& Developmental Biology Plant, 40:396-402.

Mills D \& Tal M (2004) The effect of ventilation on in vitro response of seedlings of the cultivated tomato and its wild salt-tolerant relative Lycopersicon pennellii to salt stress. Plant Cell, Tissue and Organ Culture, 78:209-216. 
Murashige T \& Skoog F (1962) A revised medium for rapid growth and bioassays with tobacco tissue cultures. Physiologia Plantarum, 15:473-497.

Nguyen QT, Kozai T, Heo J \& Thai DX (2001) Photoautrotophic growth response of in vitro cultured coffee plantlets to ventilation methods and photosyntetic photon fluxes under carbon dioxide enriched condition. Plant Cell, Tissue and Organ Culture, 66: 215-225.

Park SW, Jeon JH, Kim HS, Park YM, Aswath C \& Joung H (2004) Effect of sealed and vented gaseous microenvironments on the hyperhydricity of potato shoots in vitro. Scientia Horticulturae, 99:199205.
Pérez-Tornero O, Egea J, Olmos E \& Burgos L (2001) Control of hyperhydricity in micropropagated apricot cultivars. In Vitro Cellular \& Developmental Biology Plant, 37:250-254.

Seko Y \& Nishimura M (1996) Effect of $\mathrm{CO}_{2}$ and light on survival and growth of rice regenerants growth in vitro on sugar-free medium. Plant Cell, Tissue and Organ Culture, 46:257-264.

Silva AB, Pasqual M, Castro EM, Miyata LY, Melo LH \& Braga FT (2008) Luz natural na micropropagação do abacaxizeiro. Interciencia, 33:839-843.

Silva EF, Pasqual M, Paiva PDO, Silva AB \& Nogueira DA (2005) Polpa de banana e vitaminas do meio MS no cultivo de in vitro de orquídea. Plant cell culture and micropropagation, 1:8-12. 